631.445 .2

\author{
- Люк \\ жгородський н ціон льний університет, \\ вул. ідгірн , 46, м. жжгород, 88000, кр їн
}

озглянуто н укові погляди н дослідження генетичної природи дерново-підзолистих грунтів, підстелених щільними к рбон тними пород ми, які зводяться до еволюційного літоряду грунтів від дерново-к рбон тних до дерново-підзолистих т формув ння грунтів н товщі воднольодовикових відкл дів, які були н кл дені н кору звітрюв ння к рбон тних порід.

лючові слов : генез, еволюція, дерново-підзолисті грунти, к рбон тні породи.

ле олісся, як специфічний регіон кр їни, постійно прив блює грунтозн вців генетичним різном ніттям дерново-підзолистих грунтів. ше дослідження стосується дерново-підзолистих грунтів, підстелених щільними к рбон тними пород ми. меж х

лого олісся площі т ких грунтів порівняно незн чні (пон д 30 тис. г ), проте особливості їхньої генези з лиш ються не досить зрозумілими, кл сифік ційн н лежність $є$ неоднозн чною. ериторії, де поширені досліджув ні грунти, вирізняються особливим x p ктером грунтоутворюв льних і підстильних порід. незн чних відст нях можуть тр плятися різні з генезою і літологією породи (водно-льодовикові відкл ди і відкл ди крейди), н яких, відповідно, формуються і різні типи грунтів. е спонук ло н с до з'ясув ння генези т вивчення особливостей еволюції дерново-підзолистих грунтів, підстелених щільними к рбон тними пород ми. я тем тик поки що не ст л предметом комплексного н укового н лізу, дослідники розгляд ють їі фр гмент рно, перев жно у формі окремих тез, рідше публік цій.

мойлов 3 зн ч л т ке: для того, щоб глибше пізн ти особливості грунтового покриву певного регіону, вл стивості грунтів, які формуються в конкретний період, необхідно зн ти їхню еволюцію, гіпотези походження т історію розвитку з г лом [7, с. 3]. чення про еволюцію грунтів сформов ні. окуч євим і є однією із в жливих скл дових ч стин з снов ного ним генетичного грунтозн вств . чений одним із перших дослідив зн чний вплив грунтоутворюв льних порід н процеси грунтоутворення [4, с. 34]. роте н сьогоднішньому ет пі розвитку грунтозн вчої н уки, коли н копичений зн чний ф ктичний м тері л з морфологічних т фізико-хімічних вл стивостей цих грунтів, виникл необхідність вивчення їхньої генези й еволюції. е, без сумніву, д сть змогу вирішити низку генетичних проблем і внесе уточнення в окремі л нки кл сифік ції грунтів.

ході дослідження еволюції дерново-підзолистих грунтів, підстелених щільними к рбон тними пород ми, доцільно використовув ти порівняльно-геогр фічний метод [2], який, з . оде (1974), поляг є в тому, що у досліджув ному р йоні визн ч ють серію грунтів, які з озн к ми утворюють певний еволюційний ряд. обто н підст ві

(C) люк ., 2012 
їхніх озн к можн припустити, що грунти певного ряду х р ктеризують послідовні ст дії одного й того ж процесу грунтоутворення. кщо водноч с н ліз умов грунтоутворення з свідчує, що одн з них більш-менш з кономірно змінюється від першого до ост ннього член ряду, то з ст лості інших умов визн чену зміну грунтоутворення можн вв ж ти причиною еволюції [7, с. 75]. ля дослідження еволюції грунтів н йч стіше використовують метод літорядів, коли в еволюційний ряд вибудовують грунти, які формуються н різних м теринських пород х. звич й це породи, які містять різну кількість к рбон тів. ей просторовий ряд розгляд ють як ч совий, оскільки грунти н пород х 3 великою кількістю к рбон тів є молодшими, ніж грунти $з$ їхнім меншим вмістом, ув ж ючи, що в основі еволюції у цьому вип дку є вилуговув ння к рбон тів. к прикл д т кого еволюційного ряду можн н вести т кий: дерново-к рбон тні грунти $\rightarrow$ дерново-к рбон тні вилугув ні $\rightarrow$ дерново-підзолисті 3 лишково-к рбон тні $\rightarrow$ дерново-підзолисті грунти. зн чимо, що у н уковій літер турі досліджув ні дерновопідзолисті грунти, підстелені щільними к рбон тними пород ми тр пляються т кож під н звою дерново-підзолисті з лишково-к рбон тні грунти. ому вони, без сумніву, вписуються в т кий еволюційний літоряд грунтів.

рунти досліджув ного еволюційного ряду досяг ють зрілості через певний проміжок ч су. д ними - мойлової, у процесі с морозвитку дерново-к рбон тні грунти переходять у дерново-підзолисті, коли з 2 тис. років н ст є ст дія брюніфіков ної рендзини, 34 тис. років - бурого к льциморфного грунту, який містить близько $2 \%$ 3, для утворення дерново-підзолистого грунту, вилугув ного від к рбон тів н глибину приблизно 1,5 м, потрібно близько 10 тис. років, і чим вологіший клім т, тим швидший процес його вилуговув ння й опідзолення [6, с. 150-151].

тже, основою еволюційного ряду дерново-к рбон тних грунтів т утворення дерново-підзолистих треб вв ж ти процес вилуговув ння к рбон тів. процесі еволюції т ких грунтів меж вилугув ного горизонту опуск ється в міру розчинення і винесення вільних к рбон тів, які містяться у верхній ч стині профілю. рбон ти глибших горизонтів грунту у цьому вип дку м йже не розчиняються, оскільки волог , як н дходить 3 верхніх горизонтів, уже н сичен к рбон т ми і не може їх розчинити в нижчих горизонт х. більшення потужності генетичних горизонтів грунту відбув тиметься услід 3 зрост нням вилугув ної товщі. ісля винесення вільних к рбон тів з усього грунтового профілю його розвиток буде н ближув тись до розвитку грунту н безк рбон тних пород х [7, с. 37-38]. тже, ріст генетичних горизонтів т ких профілів трив є доти, доки не будуть винесені всі к рбон ти з грунтової товщі. ісля цього біоклім тичні чинники вільно вз ємодіють з літогенними і профіль грунту н був є стійкого ст ну. оли зрост є вік грунту, простежується ускл днення профілю нових генетичних горизонтів, збільшення потужності елюві льного т модифік ції ілюві льного горизонтів.

к тільки процеси внутрішньогрунтового звітрюв ння утворили кв зірівнов жний продукт, н ст є ст дія дин мічної зрілості грунту. нтегр льним пок зником зрілості грунтів є $б$ л нс речовин. ідомо, що у зрілому грунті т кий пок зник близький до нульового, в незрілому він різко від'ємний чи дод тний. и розр хув ли пок зники 6 л нсу компонентів у досліджув них грунт х лого олісся. н слідок порівняння з п сів у дерново-підзолистих грунт х, підстелених щільними к рбон тними пород ми, з дерново-к рбон тними грунт ми виявлено, що у перших з п си оксидів к льцію н 6 г то нижчі. прикл д, у генетичних горизонт х дерново-підзолистих грунтів, підстелених щільними к рбон тними пород ми, ці зн чення ст новлять 0,16- 


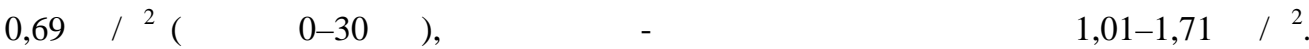
ншими пок зник ми дин міки розвитку грунтів є 3 п си півтор оксидів т силіцію. г лом формув ння грунтів н в пняк х веде до їхнього зб г чення півтор оксид ми, менше - силіцієм, к лієм. дн к у процесі еволюції вміст півтор оксидів зменшується, вміст силіцію з кономірно збільшується. держ ні результ ти розр хунків б л нсу півтор оксидів у грунт х лого олісся з свідчують, що в дерново-к рбон тних грунт х ці з п си є вищими, ніж у дерново-підзолистих, підстелених щільними к рбон тними пород ми. підст ві цього робимо висновки, що дерново-підзолисті грунти, підстелені щільними к рбон тними пород ми, є еволюційно “ст ршими”, ніж суч сні дерново-к рбон тні грунти, в процесі еволюції сягнуть ост нньої л нки, утворивши звич йний тип дерново-підзолистих грунтів.

нш гіпотез формув ння дерново-підзолистих грунтів, підстелених щільними к рбон тними пород ми, пов'яз н з діяльністю льодовик і т лих льодовикових вод у четвертинний період. скільки відомо, що потужні потоки т лих вод розмив ли, переносили і перевідкл д ли зн чні м си пухких н носів у кр йових обл стях льодовик , то можн припустити, що грунтоутворюв льн пород порівняно зрідк предст влен однорідною товщею зн чної потужності, грунти можуть формув тися не н одній, н декількох пород х, коли одн змінюе іншу в меж х грунтового профілю. т кому вип дку йдеться про підстильні породи. . оз нов і . овд [3,5] з зн ч ли, що т кі породи особливо поширені в постгляці льних обл стях, де особливо ч сто спостеріг ють зміну і ш рув тість поверхневих відкл дів. йч стіше грунти формуються н пород $\mathrm{x}$, верхня ч стин яких предст влен легшими пород ми порівняно з нижчим ш ром.

рунтоутворюв льними пород ми лого олісся є перев жно утворення четвертинного періоду різної потужності т крейдові відкл ди. уйнув ння крейдової товщі роботою льодовик , розмив ння і перевідкл дення водно-льодовикових відкл дів зумовили формув ння двочленної грунтоутворюв льної породи. одно-льодовикові відкл ди у процесі грунтоутворення зб г чув лись к рбон тним м тері лом ун слідок дек рбоніз ції мергелів т в пняків, т кож з вдяки впливу жорстких к рбон тних вод н сичув лись к льцієм. досліджув них грунт х потужність четвертинних відкл дів незн чн (у середньому до 0,3-0,5 м), одн к дуже ч сто вони н стільки м лопотужні, що під ч с грунтоутворення повністю входять у перехідний до породи горизонт, створюючи видимість грунтів, розвинених безпосередньо н к рбон тних пород х. н слідок вз ємодії чинників грунтоутворення в ілюві льних т перехідних горизонт х т ких грунтів утворились скупчення ул мків к рбон тів.

ляг ння водно-льодовикових відкл дів н пород х, 6 г тих н елементи зольного живлення (особливо к рбон тних), позн ч ється н всіх елемент рних грунтових процес х. ослідження грунтоутворення н подібних пород х у зоні лісостепу викон не . емезовим (1951). ін з зн ч в, що з н ближенням к рбон тних порід до поверхні суттєво поліпшується водний і поживний режим лісу; у видовому скл ді з'являються і домінують вимогливі деревні породи (дуб) [6, с. 126-127]. тже, підстильні породи опосередков но, через біологічний колообіг, можуть к рдин льно змінюв ти х р ктер грунтоутворення.

ітологічні відмінності ш рів здебільшого зумовлені не лише грунтоутворюв льним процесом, й різном нітністю с мих н носів, їхньою різною генезою. т кому вип дку грунтоутворюв льний процес з лежить від кінцевого скл ду породи, скл д м теринської породи з лежить не лише від клім тичних умов звітрюв ння, й від рель- 
єфу, водопроникності, ер ції. н чною мірою він зумовлений і вихідними чи підстильними пород ми. уттєве різном ніття скл ду грунтоутворюв льних порід призводить до того, що в одних і тих же клім тичних умов х н різних пород х формуються різні типи грунтів. е явище одерж ло н зву літогенної дивергенції грунтоутворення [1, c. 99]. рикл дом літогенної дивергенції грунтоутворення н території лого олісся $є$ поєдн ння ре лів дерново-к рбон тних грунтів, дерново-підзолистих грунтів, підстелених щільними к рбон тними пород ми, т дерново-підзолистих грунтів н воднольодовикових відкл д х. ричому, очевидно, що дерново-к рбон тні грунти є молодими грунт ми, дерново-підзолисті - зрілими. ечовинний скл д і вл стивості порід н йрізкіше вплив ють н вл стивості молодих грунтів. пізніших ет п х розвитку вл стивості грунтів, які формуються в одних біоклім тичних умов х н різних пород х, ст ють подібними з кількісними т якісними пок зник ми, проте вони пр ктично ніколи повністю не збіг ються. рикл дом т кої подібності є дерново-підзолисті грунти, підстелені щільними к рбон тними пород ми т дерново-підзолисті грунти н воднольодовикових відкл д х.

тже, н підст ві н лізу літер турних джерел т вл сних експеримент льних досліджень стосовно генези й еволюції дерново-підзолистих грунтів, підстелених щільними к рбон тними пород ми, з зн чимо про скл дність і проблем тичність цього пит ння, оскільки погляди н уковців різном нітні, елемент рні процеси в грунт х досить скл дні. , як н слідок, в жко, чи н віть не доцільно виділяти одну з гіпотез, як ост точну. дже досліджув ні грунти з озн к ми і вл стивостями в одному вип дку є т кими, що сформув лись н пород х, які звітрились, інші м ють озн ки і рештки водно-льодовикових н носів.

1. обровольский . . еогр фия почв / . . обровольский, . . русевск я. - . : зд-во оск. ун-т , 2004. -460 с.

2. в нов . . етоды исследов ния эволюции и возр ст почв / . . в нов, . . лекс ндровский. - ущино, 1984. -54 с.

3. овд . . сновы учения о почв х. бщ я теория почвообр зов тельного процесс / . овд . - . : у ук , 1973. - н. 1. -432 с.

4. огин . . влияние пород н процессы почвообр зов ния / . . огин , . . оде // очвоведение. - 1959. - № 10. - . 34-43.

5. оз нов . . орфология почв / . . оз нов. - . : зд-во оск. ун-т, 1983. -320 с.

6. мойлов . . очвообр зующие породы / . . мойлов . - . . зд-во оск. ун-т , 1983. $-173 \mathrm{c}$.

7. мойлов . . волюция почв / . . мойлов , . . ольчеников. - . : зд-во оск. унт , 1991. $-90 \mathrm{c}$. 


\title{
GENESIS AND EVOLUTION OF SOD-PODZOL SOILS WITH UNDERLING COMPACT CARBONATES
}

\begin{abstract}
M. Saliuk
National University of Uzhorod, Pidhirna St., 46, Uzhgorod, 88000, Ukraine

Modern researches of genetic nature of sod-podzol soils with underling carbonates are considered in the article. They are erected to evolutional row from rendzina to sod-podzol soils and forming soils on the layer of water-glacial with were put on carbonates rocks.

Key words: genesis, evolution, sod-podzol, soils, carbonic rocks.

\section{- Люк}

жгородский н иион льный университет ул. одгорн я, 46, г. жггород, 88000, кр ин

ссмотрено н учные взгляды н исследов ния генетической природы дерново-подзолистых почв, подстил емых плотными к рбон тными пород ми. ни сводятся к эволюционному литоряду от дерново-к рбон тных к дерново-подзолистым и формиров ние почв н толще водно-ледниковых отложений, которые были н ложены н кору выветрив ния к рбон тных пород.
\end{abstract}

лючевые слов : генезис, эволюция, дерново-подзолистые, почв , к рбон тные породы. 